\title{
Keampferol-3-O-rhamnoside abrogates amyloid beta toxicity by modulating monomers and remodeling oligomers and fibrils to non-toxic aggregates
}

Md Golam Sharoar ${ }^{1,4^{*}}$, Arjun Thapa ${ }^{5}$, Mohammad Shahnawaz $^{6}$, Vijay Sankar Ramasamy ${ }^{1}$, Eun-Rhan Woo ${ }^{3}$, Song Yub Shin ${ }^{1,2}$ and II-Seon Park ${ }^{1,2^{*}}$

\begin{abstract}
Background: Aggregation of soluble, monomeric $\beta$ - amyloid $(A \beta)$ to oligomeric and then insoluble fibrillar $A \beta$ is a key pathogenic feature in development of Alzheimer's disease (AD). Increasing evidence suggests that toxicity is linked to diffusible $A \beta$ oligomers, rather than to insoluble fibrils. The use of naturally occurring small molecules for inhibition of $A \beta$ aggregation has recently attracted significant interest for development of effective therapeutic strategies against the disease. A natural polyphenolic flavone, Kaempferol-3-O-rhamnoside (K-3-rh), was utilized to investigate its effects on aggregation and cytotoxic effects of A 42 peptide. Several biochemical techniques were used to determine the conformational changes and cytotoxic effect of the peptide in the presence and absence of K-3-rh.
\end{abstract}

Results: K-3-rh showed a dose-dependent effect against Aß42 mediated cytotoxicity. Anti-amyloidogenic properties of K-3-rh were found to be efficient in inhibiting fibrilogenesis and secondary structural transformation of the peptide. The consequence of these inhibitions was the accumulation of oligomeric structural species. The accumulated aggregates were smaller, soluble, non- $\beta$-sheet and non-toxic aggregates, compared to preformed toxic A $\beta$ oligomers. K-3-rh was also found to have the remodeling properties of preformed soluble oligomers and fibrils. Both of these conformers were found to remodel into non-toxic aggregates. The results showed that K-3-rh interacts with different $A \beta$ conformers, which affects fibril formation, oligomeric maturation and fibrillar stabilization.

Conclusion: $\mathrm{K}$-3-rh is an efficient molecule to hinder the self assembly and to abrogate the cytotoxic effects of A 42 peptide. Hence, $\mathrm{K}-3-\mathrm{rh}$ and small molecules with similar structure might be considered for therapeutic development against AD.

Keywords: A $\beta$, Kaempferol-3-O-rhamnoside, Oligomer, Aggregation, Cytotoxicity, Alzheimer's disease

\section{Background}

Alzheimer's disease (AD) is characterized by progressive and insidious neurodegeneration of the central nervous system, which eventually leads to a gradual decline of cognitive function and dementia [1]. The principal neuropathological features of $\mathrm{AD}$ are the presence of

\footnotetext{
* Correspondence: sharoarmg@ru.ac.bd; parkis@chosun.ac.kr

'Department of Bio-materials Engineering, Chosun University, Gwanju

501-759, Republic of Korea

2Department of Cellular and Molecular Medicine, Chosun University, Gwanju 501-759, Republic of Korea

Full list of author information is available at the end of the article
}

intracellular neurofibrillary tangles and extracellular deposition of amyloid beta $(A \beta)$ peptides in the form of senile plaques [2]. The peptide is derived from amyloid precursor protein (APP) by sequential cleavage of $\alpha-, \beta-$, and $\gamma$ - secretases [3]. Differential cleavage by $\gamma$-secretase is one factor contributing to formation of $A \beta$ with different $\mathrm{C}$-termini. Among the two most common alloforms of $A \beta, A \beta 40$ (ending at Val at 40 position) and $A \beta 42$ (ending at Ala at 42 position), the longer form(A $\beta 42)$ is more prone to aggregation than the shorter form(A $\beta 40)$, and is the main constituent of senile plaques [4].

\section{Biomed Central}


The native $A \beta$ peptides spontaneously undergo conformational changes to form $\beta$-sheets rich insoluble fibril through fibrillization process. Fibrillization follows nucleation-dependent aggregation, which basically comprises two phases; nucleation, the formation of the nucleus by association of a series of monomeric peptides [5], and extension, the subsequent addition of monomers to the end of the existing nucleus [6]. However, A $\beta$ fibrillization derives several transitional species including trimer, pentamer, or higher molecular weight complex, also known as A $\beta$-derived diffusible ligands (ADDLs) [7], oligomers composed of 15-20 monomers [8], protofibrils (string of oligomers) [9], and dodecameric oligomers $A \beta$ *56 [10]. All of these unstable intermediates are collectively designated as "soluble A $\beta$ " [11]. Recent studies have reported that the soluble $A \beta$ oligomers formed during early aggregation are the main cytotoxic agents rather than monomeric or fibrilar forms [12]. Therefore, preventing the assembly of $\mathrm{A} \beta$ monomer into toxic oligomer or fibril is the primary goal of a number of therapeutic strategies under development or in clinical trials. Hence, major research has involved the development of compounds capable of inhibiting or reversing the $A \beta$ aggregation process. Thus far, a number of diverse compounds including small molecules $[13,14]$, antibodies [15], peptidic $\beta$-sheet breakers $[16,17]$, and osmolytes [18], have been used to prevent or to reduce the aggregation of $\mathrm{A} \beta$ into oligomers or fibrils. Small molecules have been reported to inhibit single or multiple steps of the $A \beta$ fibrillization process [19]. In addition, small molecules that efficiently inhibit the early steps of $A \beta$ fibrillogenesis and stabilize its nontoxic conformations have been considered as possible AD therapeutics, because the self-assembly of the peptide is directly linked to the pathogenesis of $\mathrm{AD}$. Among the $\mathrm{A} \beta$ interacting small molecules, curcumin is one of the most attractive compounds to scientists due to its direct capability to bind with small $A \beta$ species, to block aggregation and fibril formation and to disaggregate mature fibrils under both in vitro and in vivo conditions [20]. Other A $\beta$ binding molecules includes sulfonate dye Congo red [21] and thioflavin $\mathrm{T}(\mathrm{ThT})$ [22], which are utilized as classic reagents for determination of characteristic $\beta$-sheet mediated fibrillization. In fact, the most of reported small molecule $A \beta$ inhibitors are structurally similar to Congo red and ThT, in that they are planar and aromatic compounds.

Flavonoids, found ubiquitously in plants, are the most common polyphenolic compounds group in human diet form [23]. This group of compounds has several beneficial effects on human health such as anti-oxidant [24], anti-allergic, anti-cancer and anti-inflammatory [25], and anti-microbial [26] activities. Flavonoids are also reported to decrease the risk of age related dementia [27]. Extensive studies on Ginkgo biloba extracts HE208 [28] and EGb 761 [29] indicate that the flavonoid molecules are essential for anti-amyloidogenic and anti-apoptotic activity in neural cells. A number of isolated flavonoids have been found to be effective against oligomer formation, fibril stabilization and cytotoxic effects of $\mathrm{A} \beta$ peptide [30-34]. On the other hand, some polyphenoles are reported to be inhibited $A \beta$ fibrilogenesis, but not $A \beta$ mediated cytotoxicity, while others described as cytoprotective, but not antifibrillogenic against $\mathrm{A} \beta[35,36]$. Hence, the correlation of anti-amyloidogenic activity and anti-cytotoxic effect of flavonoids remains unclear. In the current study, we screened several phenolic compounds against cytotoxic effects of $A \beta$ peptide. We identified a polyphenolic glycoside flavone, Keampferol-3-rhamnoside (K-3-rh), as an effective molecule for alteration of the on pathway aggregation of different $A \beta$ conformers to off pathway nontoxic species, as well as for disaggregation preformed mature fibrils.

\section{Methods}

\section{Materials}

K-3-rh, quercitrin (Q) and keampferol-3-rutinoside (K-3$\mathrm{ru}$ ) were purchased from Sigma (St. Louis, USA). Gallic acid (GA), protocatechuic acid (PA), gallic acid methyl ester (GAME), quercetin dihydrate (Quer-di-hy), quercetin hydrate (Quer-hy) and kaempferol (K) are isolated as described earlier [37]. Fetal Bovine Serum (FBS) was purchased from Life Technology Inc. (Grand Island, USA). Dulbecco's modified Eagles medium, Ham's F 12 (1:1) (DMEM/F-12) was obtained from Welgene (Daegu, Korea). Western blotting detection kit (WEST-ZOL plus) was purchased from iNtron Biotechnology (Gyeonggi-do, Korea). Phosphate buffered saline (PBS) was purchased from Amresco (Solon, USA). Monoclonal anti-A $\beta$ antibody 6E10 was acquired from Signet Laboratories (Dedham, USA). Urea was obtained from USB chemicals and acetonitrile was from Merck (Darmstadt, Germany). All other chemicals were obtained from Sigma (St. Louis, USA), unless otherwise stated.

\section{Preparation of amyloid beta}

Amyloid beta peptides were expressed in E.coli as fusion proteins and purified as described before [38]. The purified peptides were solubilized in $100 \% 1,1,1,3,3,3$,hexafluoro-2-propanol, and dried under nitrogen flow and subsequently, under a vacuum for $30 \mathrm{~min}$. The peptide aliquots were stored at $-20^{\circ} \mathrm{C}$ until use. Immediately before use, the peptides were dissolved in $0.1 \% \mathrm{NH}_{4} \mathrm{OH}$ at a concentration of $2 \mathrm{mg} / \mathrm{ml}$ followed by bath sonication for $10 \mathrm{~min}$ at $4^{\circ} \mathrm{C}$. The solution was diluted at the desired concentration with PBS. A $\beta 42$ oligomers and fibrils were prepared as described earlier [39] with little modification. Briefly, oligomers were prepared by diluting the peptides in cell culture media at a concentration of $100 \mu \mathrm{M}$, vortexing for 30 seconds and incubating at 
$4^{\circ} \mathrm{C}$ for $12 \mathrm{~h}$. K-3-rh accumulated oligomeric species were prepared by co-incubating A $\beta 42(20 \mu \mathrm{M})$ and $40 \mu \mathrm{M}$ K-3rh for $12 \mathrm{~h}$ and centrifuging the sample to obtain the supernatant. To make fibrils, A $\beta 42(100 \mu \mathrm{M})$ was incubated in the presence of $0.02 \%$ sodium azide in PBS at $37^{\circ} \mathrm{C}$ for four days. The samples were then centrifuged at $16000 \times \mathrm{g}$ for $30 \mathrm{~min}$. The pellet fraction (fibrils) was washed three times with PBS. Fibrils were sonicated for 10 min, quantified using the Bradford method and used immediately or stored at $-80^{\circ} \mathrm{C}$.

\section{Cell culture and cell death assay}

Human neuroblastoma SH-SY5Y was cultured in Dulbecco's Modified Eagles medium and Ham's F 12 (1:1), supplemented with $10 \%(\mathrm{v} / \mathrm{v})$ fetal bovine serum (FBS) and $1 \%$ antibiotics, at $37^{\circ} \mathrm{C}$ under $5 \% \mathrm{CO}_{2}$. Cells were seeded at a density of 15,000 cells/well in 96-well plates (Nunc, Denmark) and incubated for $24 \mathrm{~h}$. The media were replaced with serum-free media and cells were further cultured for $24 \mathrm{~h}$. For measurement of cell death, cells were treated with indicated concentrations of different $A \beta$ conformers in the presence or absence of flavonoid(s) for 12 or $24 \mathrm{~h}$. Cell viability was assessed by MTT reduction assay. Briefly, $20 \mu \mathrm{l}$ of $5 \mathrm{mg} / \mathrm{ml} \mathrm{MTT} \mathrm{so-}$ lution in PBS was added to each well and incubated for $2 \mathrm{~h}$. Then, $100 \mu \mathrm{l}$ of solubilization buffer [20\% SDS solution in 50\% (v/v) DMF ( $\mathrm{pH} 4.7)$ ] was added to each well. The absorbance was recorded after $12-16 \mathrm{~h}$ at $570 \mathrm{~nm}$ using a micro plate reader Spectra Max 190 (Molecular Devices, CA, USA).

\section{Thioflavin-T (Th-T) assays}

For the polymerization assay, A $\beta 42(20 \mu \mathrm{M})$ was incubated in PBS at $37^{\circ} \mathrm{C}$ in the presence or absence of $\mathrm{K}-3$-rh in a final volume of $30 \mu \mathrm{l}$ without shaking. Twenty $\mu$ from each reaction was mixed with $80 \mu \mathrm{l}$ of $5 \mu \mathrm{M}$ Th-T in PBS solution. Fluorescence was measured on a microplate spectrofluorometer Gemini-XS (Molecular Devices CA, USA) using excitation at $440 \mathrm{~nm}$ and emission at $490 \mathrm{~nm}$ [39]. Th-T fluorescence representing the characteristic sigmoidal curve was plotted as common logarithms in the equation: $\log [F(t) / A-F(t)]=a t+b$, where $t$ is the reaction time, $F(t)$ is the fluorescence as a function of time, $A$ is tentatively determined as $F(\infty), a$ slope and $b$ is the $y$-intercept [40]. Differentiating the above equation by $t$ and subsequent rearrangement produced a logistic equation, $F^{\prime}(t)=$ $B F(t)[A-F(t)]$, where, $B=a \ln 10 A / 2$, and $F^{\prime}(t)$ represents rate of fluorescence increase at aiven time. When $F$ $(t)=A / 2, F(t) / A-F(t)=1$ and $F^{\prime}(t)$ reaches its maximum. This time point was referred to as $t / 2$ [40]. For the A $\beta 42$ fiber extension assay, fresh $\mathrm{A} \beta 42(20 \mu \mathrm{M})$ was incubated with preformed $\mathrm{A} \beta 42$ fibrils $(1.1 \mu \mathrm{M})$ in the presence of varying concentrations of K-3-rh. For the fibril destabilization assay, preformed A $\beta 42$ fibrils $(20 \mu \mathrm{M})$ were incubated in presence of varying concentrations of K-3-rh.

\section{Circular dichroism (CD) spectroscopy}

A $\beta 42(20 \mu \mathrm{M})$ was incubated in PBS at $37^{\circ} \mathrm{C}$ either alone or in the presence of $20 \mu \mathrm{M}$ of K-3-rh for 0 or $12 \mathrm{~h}$. CD spectra [41] were recorded using a 1-mm path length cuvette at $0.5 \mathrm{~nm}$ intervals between $190 \mathrm{~nm}$ and $250 \mathrm{~nm}$ at $1 \mathrm{~nm}$ resolution with a scan rate of $50 \mathrm{~nm} / \mathrm{min}$ using a Jasco Sectropolarimeter (Jasco Co., Tokyo, Japan) at $25^{\circ} \mathrm{C}$. Average was taken from five scans for each sample. A $\beta$ spectra were obtained by subtracting buffer background. Background spectra given by K-3-rh alone under identical conditions were subtracted from $A \beta$ samples incubated in the presence of K-3-rh. The corrected, averaged spectra were smoothed using the means-movement algorithm in the Jasco spectra analysis program.

\section{Transmission Electron Microscopy (TEM)}

Twenty $\mu \mathrm{M}$ native $\mathrm{A} \beta 42$, oligomeric $\mathrm{A} \beta 42(\mathrm{OA} \beta 42)$ or fibrilar $A \beta 42$ (fA $\beta 42$ ) either alone or in the presence of $\mathrm{K}-3$-rh was incubated in $\mathrm{PBS}$ at $37^{\circ} \mathrm{C}$ for $12 \mathrm{~h}$. Five $\mu \mathrm{l}$ of sample was adsorbed on Formvar-coated 200-mesh nickel grids for $30 \mathrm{~min}$ and extra solution was wiped off [42]. The grids were negatively stained with $2 \%$ uranyl acetate for $1 \mathrm{~min}$ and washed at least three times with distilled water. The samples were then analyzed using transmission electron microscopy (Hitachi, Japan) at an accelerating voltage of $80 \mathrm{kV}$ at magnification of 40,000x.

\section{Detection of $A \beta$ structural species by immunoblotting}

Twenty $\mu \mathrm{M}$ native $\mathrm{A} \beta 42$ was incubated in PBS at $37^{\circ} \mathrm{C}$ without or with indicated amounts of K-3-rh for 12 and 24 h. $2 \mu \mathrm{l}$ from each reaction mixture was diluted with $8 \mu \mathrm{l}$ or $6 \mu \mathrm{l}$ (for cross link reaction) of PBS. For control $(0 \mathrm{~h})$ fresh $\mathrm{A} \beta 42$ was diluted to a concentration of $20 \mu \mathrm{M}$ in PBS and from there $2 \mu \mathrm{l}$ was taken. $2 \mu \mathrm{l}$ of SDS buffer [50 mM Tris buffer ( $\mathrm{pH}$ 6.8), 10\% glycerol, 2\% SDS, and $0.1 \% \beta$-mercaptoethanol] was then added to each sample. Crosslinking of the peptide in the reaction mixture was performed as described previously [43], with slight modification. Briefly, before addition of SDS buffer, each sample was incubated with $0.01 \%$ glutaraldehyde (v/v) in PBS ( $2 \mu \mathrm{l}$ from a $0.05 \%$ stock solution) for $10 \mathrm{~min}$. The crosslinking reaction was then terminated with an equal volume of SDS buffer. Samples were then run on a SDSPAGE gel (16\% acrylamide) without boiling. Subsequently, the peptide was transferred to polyvinylidene difluoride (PVDF) membrane. After blocking with 5\% milk in Trisbuffered saline containing $0.2 \%(\mathrm{v} / \mathrm{v})$ Tween 20 at room temperature for $1 \mathrm{~h}$, the membranes were probed with anti-A $\beta$ antibody $6 \mathrm{E} 10(1: 10,000)$. The blots were then incubated with horseradish peroxidase-conjugated Ig anti- 
mouse antibody $(1: 5,000)$ for $1 \mathrm{~h}$ at room temperature and developed using a West-zol plus kit.

\section{Statistical analysis}

All experiments were performed in triplicate. For each experiment, data are expressed as the mean \pm standard error (SE, $\mathrm{n}=3$ ) and statistical significance was assessed by one-way analysis of variance (ANOVA) and Student's t-tests. A $p$ value of $<0.05$ was considered significant.

\section{Results}

\section{$\mathrm{K}-3-\mathrm{rh}$ and related flavonoids are cytoprotective against A 342 toxicity}

Flavonoids are suggested to be neuroprotective against several stress or toxic compounds. In the current study, first we screened nine available phenolic compounds (Figure 1) for their protective effects against $A \beta 42$ toxicity to human neuroblastoma SH-SY5Y cells. Treatment with $20 \mu \mathrm{M}$ of the peptide for $12 \mathrm{~h}$ resulted in a decrease of cell viability to $\sim 50 \%$. The most of the flavonoids $(20 \mu \mathrm{M})$ enhanced cell viability to different extents (Figure 2A). Cell viability enhancement of approximately 25-30\% was observed for K-3-rh, Q, K-3-ru, Quer-di-hy, and K. Treatment with compounds such as Q, GAME, and Quer-di-hy alone was found to result in decreased cell viability (Figure 2A). Notably, the most of the polyphenolic flavonoids (Figure 1) found to be more effective than monophenolic compounds for protection of cells against $\mathrm{A} \beta$ toxicity (Figure $2 \mathrm{~A}$ ).

Cytoprotective effects of the flavonoids, which showed better efficiency in inhibition of $A \beta$ induced cell death (Figure 2A) and are relatively similar structurally (Figure 1), were further explored for their dose-dependent consequence (Figure 2B). Cell survival was found to be enhanced by increasing the concentration of K-3-rh, where $20 \mu \mathrm{M}$ of the compound enhanced $30 \%$ cell survival (Figure 2B). On the other hand, dose-dependent effects on protection of cells against $A \beta$ toxicity were found to be flattened at $>20 \mu \mathrm{M}$ for $\mathrm{Q}$ and $\mathrm{K}-3$-ru (Figure $2 \mathrm{~B}$ ). This might be due to the toxic effect of $\mathrm{Q}$ and $\mathrm{K}-3$-ru on cells, because both of these chemicals were found to decrease cell survival at a higher concentration when applied without $A \beta$ (data not shown). On the other hand, no toxic effect of treatment with $\mathrm{K}$-3-rh alone was observed, even at $50 \mu \mathrm{M}$ (data not shown). The $\mathrm{EC}_{50}$ values calculated as $14.82 \pm 1.09,23.10 \pm$ 7.60 and $24.00 \pm 2.90 \mu \mathrm{M}$ for K-3-rh, $\mathrm{Q}$ and K-3-ru,<smiles>Cc1ccc(-c2oc3cc(C)cc(C)c3c(=O)c2Oc2cc(C)cc(C)c2C(=O)C(C)C)cc1</smiles>

Kaempferol-3-O-rhamnoside (K-3-rh)<smiles>COc1cc(O)c(O)c(O)c1</smiles>

Gallic acid (GA)

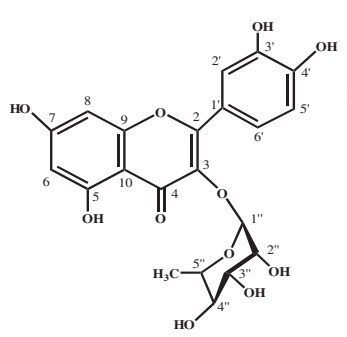

Quercitrin (Q)<smiles>O=Cc1ccc(O)c(O)c1</smiles>

Protocatechuic acid (PA)

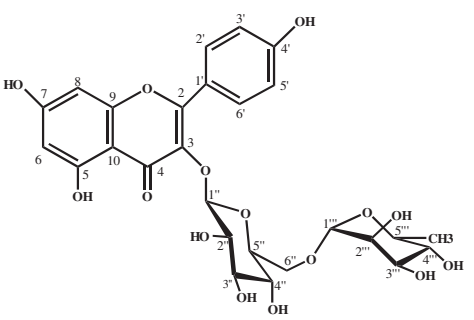

Kaempferol-3-O-rutinoside (K-3-ru)<smiles>COc1cc(O)c(O)c(O)c1</smiles>

Gallic acid methyl ester (GAME)<smiles>Cc1cc(C)c2c(=O)c(OC3O[C@H](C)[C@@H](C)[C@H](C)[C@H]3C)c(-c3ccc(C)c(C)c3)oc2c1</smiles>

Quercetin hydrate (Quer-hy)<smiles>O=c1c(O)cc(O)cc2oc(-c3ccc(O)cc3)c(O)c12</smiles>

Kaempferol (K) 


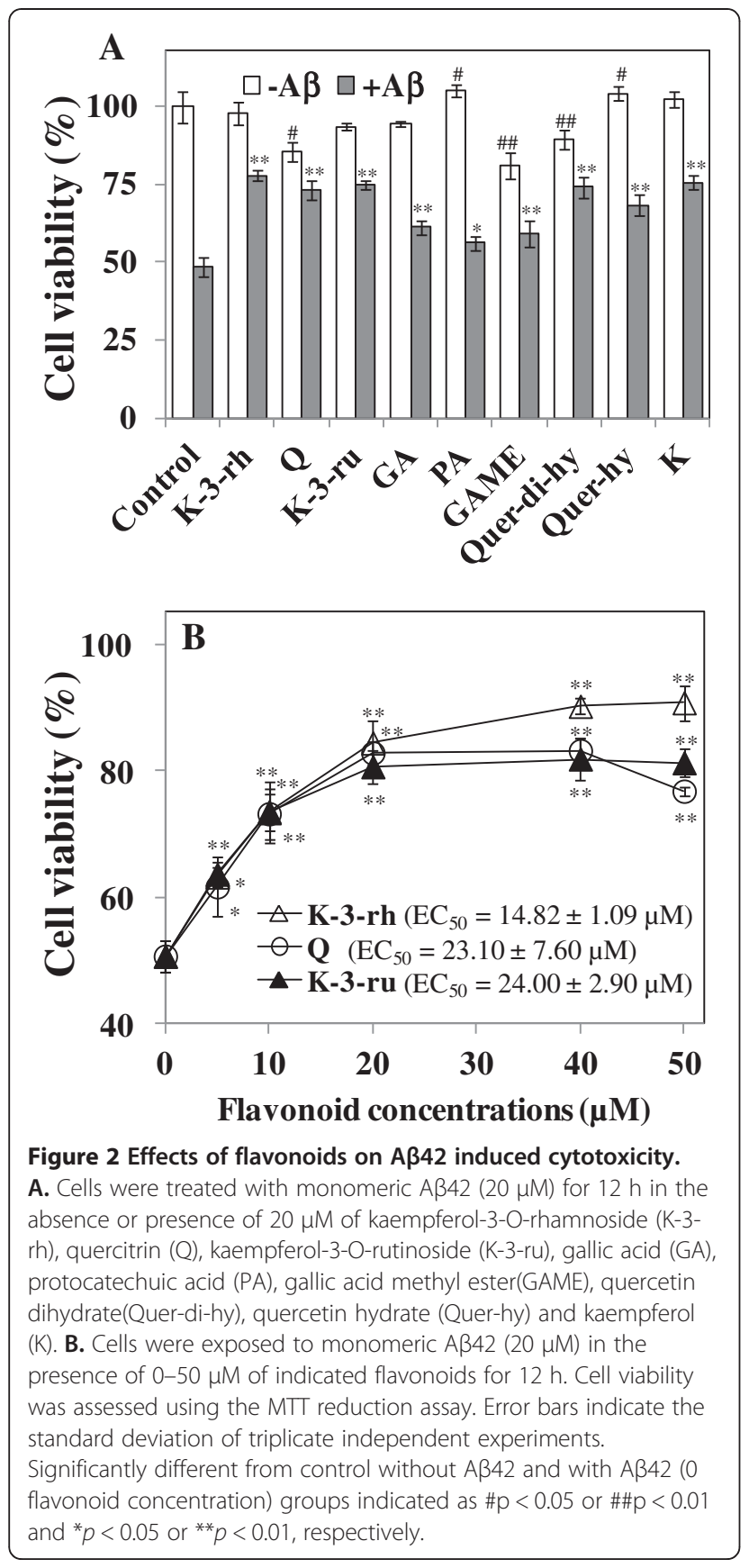

respectively. The results indicated that K-3-rh is an efficient compound for protection against $\mathrm{A} \beta$ induced cell death.

\section{K-3-rh inhibits fibrilogenesis and secondary structural transformation of $A \beta 42$}

To examine the effects of K-3-rh on fibril formation of $\mathrm{A} \beta 42,20 \mu \mathrm{M}$ of peptide was incubated in the presence of several concentrations of K-3-rh and Th-T assay was performed for measurement of fibrillogenesis activity.
The fluorescence profiles of $A \beta 42$ aggregation with increasing K-3-rh concentrations are shown in Figure 3A. A $\beta 42$ alone showed a characteristic sigmoidal curve when incubated at $37^{\circ} \mathrm{C}$ for $6 \mathrm{~h}$ [44]. In the presence of 0-50 $\mu \mathrm{M} \mathrm{K-3-rh,} \mathrm{the} \mathrm{final} \mathrm{fluorescence} \mathrm{level,} \mathrm{indicative}$ of the amount of mature fibrils formed, showed a dosedependent decrease (Figure 3A). Semilogarithmic plots of thioflavin $\mathrm{T}$ fluorescence versus time gave a linear relationship for the indicated time (Figure 3B). From these plots, $t / 2$ values were obtained (see Materials and Methods), which gives us information about the kinetics of the nucleation step during the early stage of fibrillogenesis [40]. It is expected that the $t / 2$ value would increase if the flavonoids inhibited the nucleation process, the rate-determining step of polymerization. $t / 2$ values for $\mathrm{A} \beta 42(20 \mu \mathrm{M})$ were calculated as $43.07,45.76,40.70$, $39.22,39.55$ and $34.10 \mathrm{~min}$. in the presence of $0,5,10$, 20,40 and $50 \mu \mathrm{M}$ of $\mathrm{K}-3$-rh, respectively. The small changes of $t / 2$ values in the presence of K-3-rh demonstrated that the marginal effect of the flavonoid in the nucleation step [40]. We also noticed the disappearance of linearity at higher concentrations of flavonoids or upon longer incubation times (Figure 3B), implying the involvement of unidentified processes and, thus, rendering the logistic equation invalid.

The fibril extension experiment was performed by incubating fresh $\mathrm{A} \beta 42(20 \mu \mathrm{M})$ with $1.1 \mu \mathrm{M}$ preformed $\mathrm{A} \beta 42$ fibrils (seed), which showed an increase of fluorescence hyperbolically without lag phase (Figure 3C) $[40,44]$. The final equilibrium of the curve showed a dose-dependent decrease in the presence of K-3-rh, indicating that the final amount of fibrils formed is decreased in the presence of the flavonoid in a concentration-dependent manner. Four perfect linear logarithmical plots with deferent y intercept were obtained by plotting logarithmic plots of fluorescence difference against times (Figure 3D). The initial rates of $A \beta$ fibril extension, the slopes of the linear portion of the fluorescence profiles, showed a dose-dependent decrease when co-incubated with K-3-rh (Figure 3E). The $\mathrm{IC}_{50}$ value against fibril extension was found to be $\sim 20 \mu \mathrm{M}$.

Structural transition to form a $\beta$-sheet structure is a characteristic feature of $\mathrm{A} \beta$ fibrillogenesis [41]. To examine the effect of K-3-rh on secondary structural transformation, A $\beta 42(20 \mu \mathrm{M})$ was incubated with or without K-3-rh $(40 \mu \mathrm{M})$ and the presence of $\beta$-sheet was detected by $\mathrm{CD}$ spectroscopy. CD spectra of $A \beta 42$ alone or with K-3-rh at $0 \mathrm{~h}$, showed a negative absolute value at approximately $\sim 200 \mathrm{~nm}$, suggesting the presence of a largely unfolded peptide at monomeric state with a significant level of random coil (Figure 3F). Upon incubation for $12 \mathrm{~h}$ at $37^{\circ} \mathrm{C}$, the peptide alone exhibited the shift of a strong signal to negative ellipticity of $\sim 220 \mathrm{~nm}$, indicating the formation of $\beta$ sheet structures of the peptide [39]. On the other hand, the 

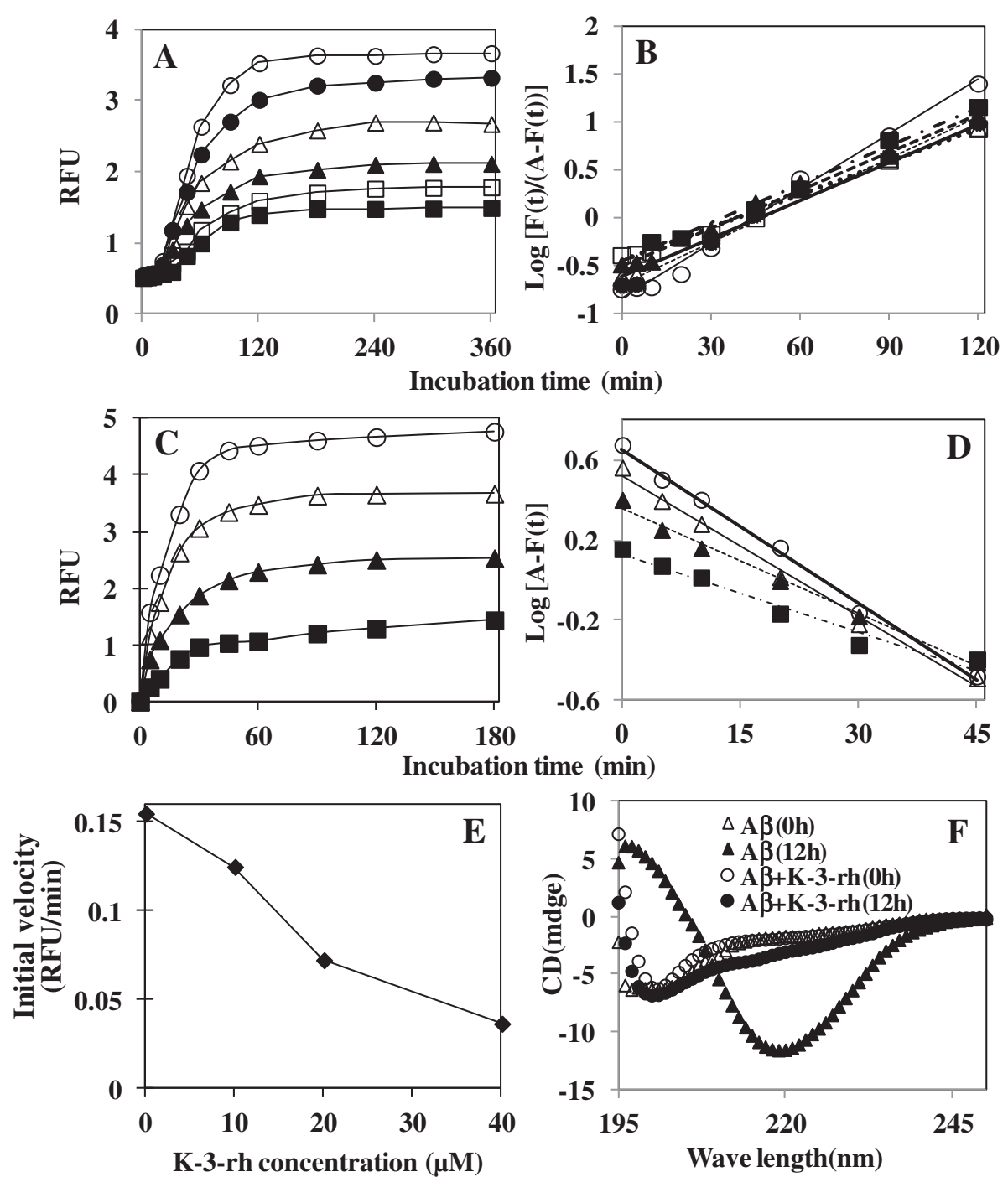

Figure 3 K-3-rh inhibits polymerization, fibril extension and secondary structural transformation of $\mathbf{A} \beta 42$. A. Inhibition of $A \beta 42$ polymerization. A $342(20 \mu \mathrm{M})$ was incubated in PBS at $37^{\circ} \mathrm{C}$ in the presence of 0 (open circle), 5 (closed circle), 10 (open triangle), 20 (closed triangle), 40 (open square) and 50 (closed square) $\mu \mathrm{M} \mathrm{K}-3-\mathrm{rh}$ for $0-6 \mathrm{~h}$. IC 50 was calculated as $30 \mu \mathrm{M}$. B. Logarithmic plot of $F(t) / A-F(t)$ versus reaction time obtained from polymerization assay. C. Inhibition of Aß42 fibril extension. Fresh Aß42 (20 $\mu \mathrm{M})$ was added to $1.1 \mu \mathrm{M}$ preformed

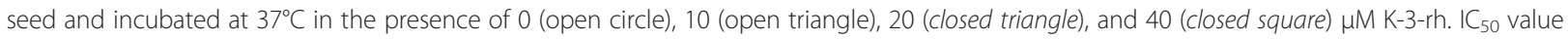
was calculated as $20 \mu \mathrm{M}$. D. Logarithmic plot of $A-F(t)$ versus reaction time obtained from the fibril extension assay. E. Effect of $A \beta 42$ concentrations on the initial rate of $A \beta 42$ fibril extension. F. Inhibition of $\beta$-sheet transformation of $A \beta 42$. The peptide $(20 \mu M)$ alone or in the presence of $\mathrm{K}-3-\mathrm{rh}(40 \mu \mathrm{M})$ was incubated in $\mathrm{PBS}$ at $37^{\circ} \mathrm{C}$ for 0 or $12 \mathrm{~h}$ as indicated. Spectra were obtained by subtracting buffer background as described in Materials and Methods section.

transition of random coil to $\beta$-sheet structure was not observed in the presence of $20 \mu \mathrm{M} \mathrm{K}-3$-rh after an incubation period of $12 \mathrm{~h}$ (Figure 3F). The results suggest that K3 -rh inhibits $\beta$-sheet formation of the peptide. All of these data suggest that K-3-rh did not have a significant impact on fibril nucleation during the lag phase (Figure 3A), however, once the rapid $A \beta$ elongation phase was initiated, the polyphenol inhibited $A \beta$ fibrillogenesis efficiently (Figure $3 \mathrm{C}$ and $3 \mathrm{E}$ ), and it obstructed the secondary structural transition of the peptide to form $\beta$-sheet structures.
K-3-rh causes accumulation of smaller $A \beta 42$ aggregates Polymerization, fibril extension and structural transition studies have shown that K-3-rh inhibits formation of A $\beta 42$ fibrils. The consequences of these inhibitions were characterized by western blot analysis and TEM. In the immunoblot assay, we used A $\beta$-specific antibody $6 \mathrm{E} 10$. A chemical cross-linker was also used to cross-link the $A \beta$ species (Figure 4C-D) prior to SDS-PAGE analysis in order to avoid SDS-induced dissociation of oligomers [39], and compared with non-crosslinking groups (Figure 4A-B). 


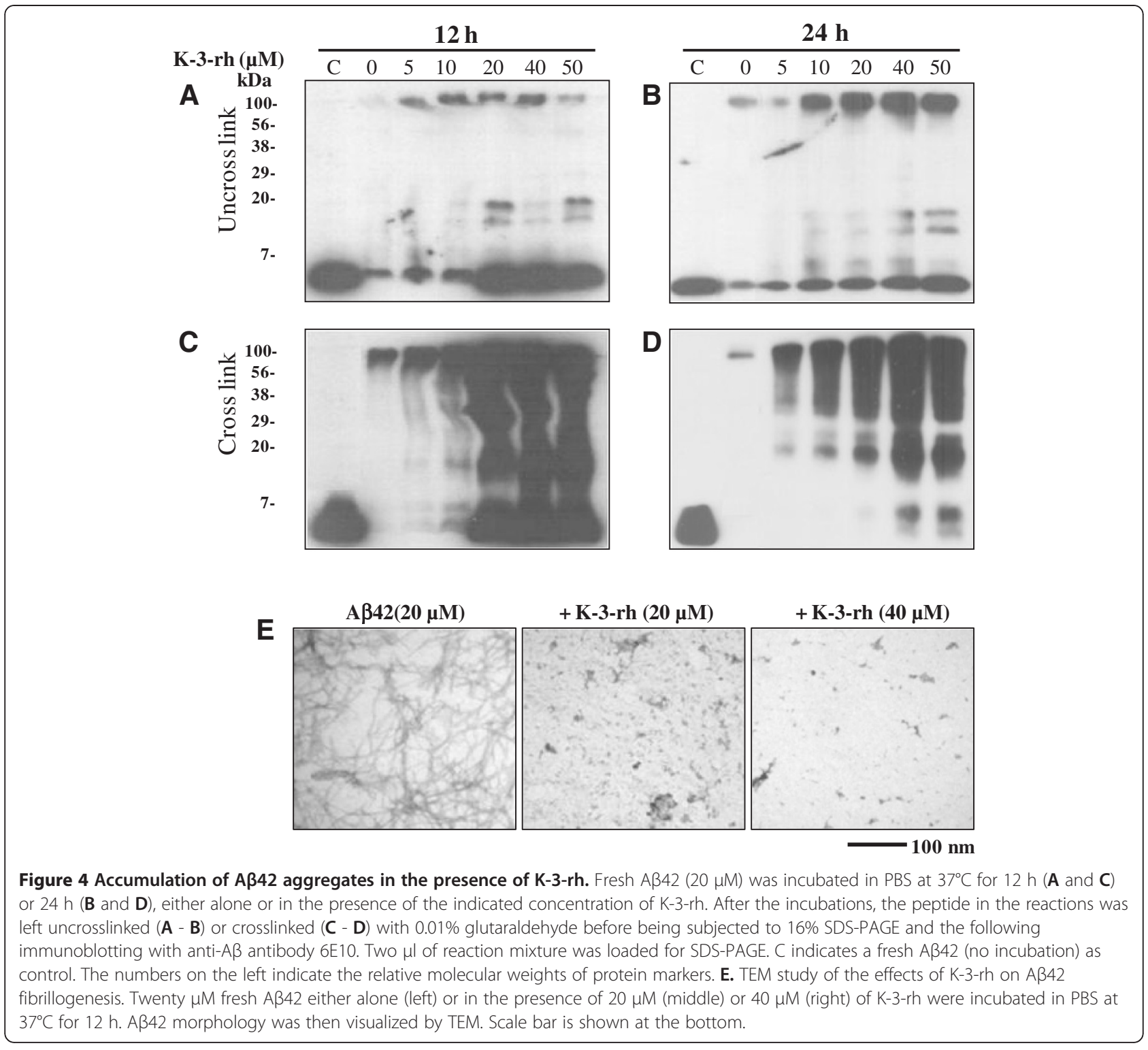

Incubation with $A \beta 42$ alone for $12 \mathrm{~h}$ resulted in the disappearance of almost all monomeric species (Figure 4A, at the bottom of the gel). In the presence of different concentrations of K-3-rh, monomeric predominant bands were observed at the bottom of the gel along with bands around the $20 \mathrm{kDa}$ area of the gel (Figure 4A and 4C), probably the intermediate aggregates of the fibrilogenesis process. These intermediate species, straddling a wide range of sizes, showed a significant increase at higher concentrations ( $20 \mu \mathrm{M}$ or more) of flavonoid. In addition, the larger aggregates were found to be enriched when incubation time was increased (Figure 4B), which was clearly observed in crosslinked samples (Figure 4D). Disappearance of monomeric $A \beta 42$ and enrichment of aggregates of several sizes in the presence of K-3-rh were obviously noted upon increasing the incubation times (Figure $4 \mathrm{~B}$ and 4D). This result suggests that accumulation of several structural species of $A \beta$ occured in the presence of K-3rh. The data are in good accordance with the earlier reports where accumulations of $A \beta$ oligomers have been observed in the presence of polyphenolic inhibitors $[39,45]$.

The above results indicate that K-3-rh causes accumulation of several intermediates including larger aggregates to small oligomeric species. To confirm the findings, the incubated samples were imaged using TEM in order to visualize the accumulated species. A $\beta 42(20 \mu \mathrm{M})$ incubated alone at $37^{\circ} \mathrm{C}$ for $12 \mathrm{~h}$, predominantly composed of typical fibrils (Figure 4E, left panel). In the presence of K-3-rh, however, fibrilar structure was absent, instead, small spherical shaped and some branched structures were observed (Figure 4E, middle and right panels). The morphology and 


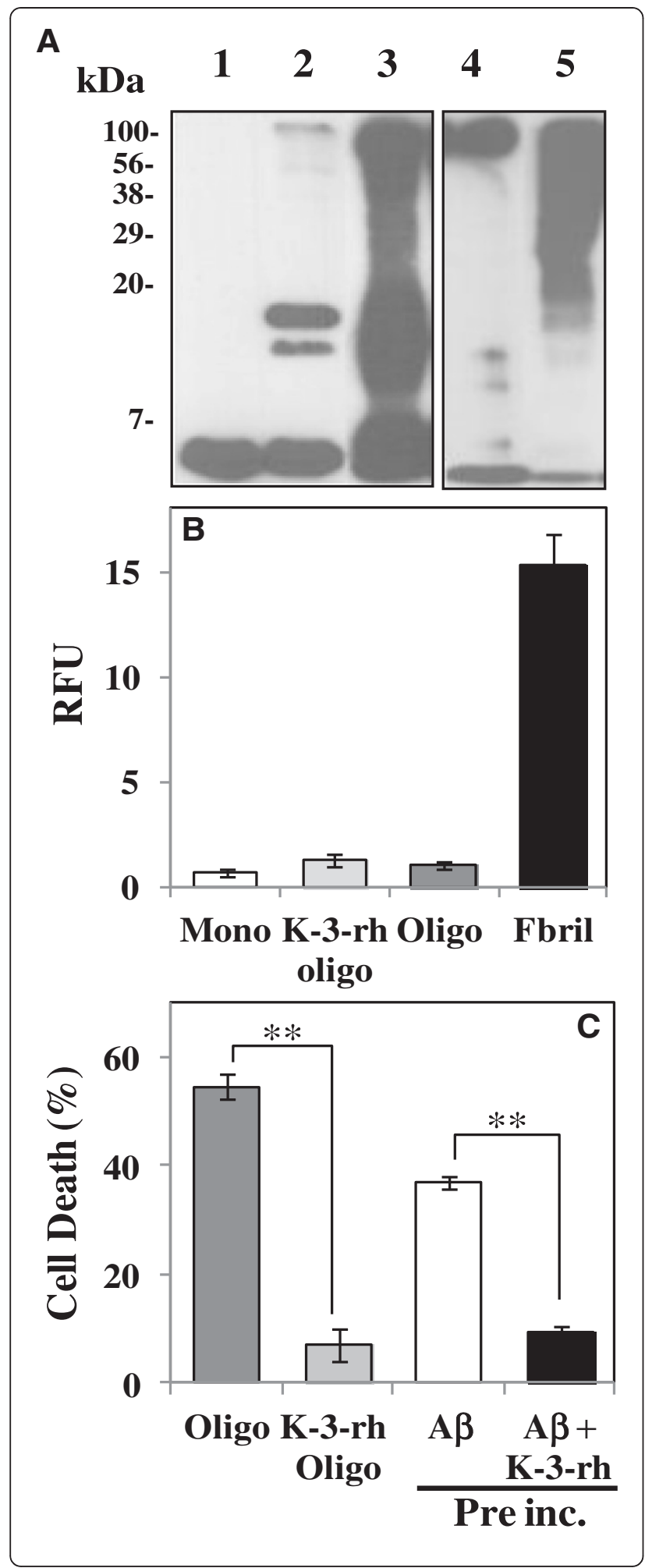

Figure 5 Biochemical characterization of accumulated $A \beta 42$ species. A. Immunoblot analysis of A 342 oligomers probed with the 6E10 monoclonal antibody: lane 1, fresh A 442 as a control; lane 2, $\mathrm{K}-3-\mathrm{rh}$ accumulated $\mathrm{A} \beta 42$ oligomers, obtained in soluble fraction by centrifuging $A \beta 42(20 \mu \mathrm{M})$ and $\mathrm{K}-3-\mathrm{rh}(40 \mu \mathrm{M})$ preincubated(12 h) sample; lane 3, Aß42 of lane 2 cross-linked before the immunoblot assay; lane 4, Aß42 subjected to the oligomerization process and recovered in the soluble fraction after centrifugation of the mixture (Aß42 preformed oligomers); lane 5, A 342 of lane 4 cross-linked before the immunoblot assay. B. Thioflavin $T$ assay of fresh monomeric A 442 as control (Mono - white bar), K-3-rh accumulated A 42 oligomers (K-3-rh Oligo - light gray bar), A 442 preformed oligomers (Oligo - dark gray bar) and A 42 mature fibrils (Fibril black bar). C. Decrease of the viability of SH-SY5Y cells (referred to as $\%$ of cell death) by A 422 preformed oligomers (Oligo - dark gray bar), K-3-rh accumulated A 42 oligomers (K-3-rh Oligo - light gray bar) and $20 \mu \mathrm{M} A \beta 42$ pre-incubated in the absence (A $\beta$ - white bar) or in the presence of $40 \mu \mathrm{M} \mathrm{K}-3-r h(A \beta+K-3-r h$ - black bar) for $12 \mathrm{~h}$. Error bars indicate the standard deviation of triplicate independent experiments and ** indicate significant different between the groups at $p<0.01$.

size of these structures are consistent with those of intermediate species previously reported $[19,46,47]$. The data clearly support the presence of different oligomeric species in $A \beta$ samples incubated with K-3-rh.

\section{K-3-rh modulated $A \beta$ oligomers are soluble, non-toxic off-}

\section{pathway aggregates}

The above results indicated that K-3-rh inhibits fibrillogenesis and $\beta$-sheet formation of $A \beta 42$ peptide. Suppression of $A \beta$ induced cell death in the presence of K-3-rh might be due to these inhibitory processes. On the other hand, inhibitory effects of K-3-rh also modulated several oligomeric intermediates of the peptide (See Figure 4A-E), and the soluble oligomeric $A \beta$ are reported to be more toxic than fresh or fibrilar $A \beta[48,49]$. Hence, we characterized the K-3-rh accumulated oligomers in order to define their size, structure and cytotoxic properties. First, we obtained the supernatant by centrifuging the $A \beta$ sample preincubated with $\mathrm{K}-3$-rh $(40 \mu \mathrm{M})$ for $12 \mathrm{~h}$ at $37^{\circ} \mathrm{C}$. We termed this soluble fraction of $A \beta 42$ as "K-3-rh accumulated oligomers (K-3-rh oligo)", which were then analyzed and compared with the preformed toxic oligomers [39].

K-3-rh accumulated soluble A $\beta 42$ was enriched with mostly smaller aggregates, which was observed as the predominant bands around the $<7 \mathrm{kDa}$ and $<20 \mathrm{kDa}$ areas of the gel (Figure 5A, lanes 2 and 3). On the other hand, mostly larger species with a size range of $\sim 20 \mathrm{kDa}$ to $>100 \mathrm{kDa}$ were visualized in preformed oligomeric A $\beta 42$ (Figure 5A, lane 4 and 5). Both oligomers were Th-T negative (Figure $5 \mathrm{~B}$ ), indicating the absence of $\beta$-sheet fibrils among them. While, the inductions of cell death by the oligomers were incomparable (Figure 5C), where preformed oligomers killed $\sim 55 \%$ of cells and K-3-rh accumulated oligomers induced only $\sim 7 \%$ cell death, suggesting the non- 
toxic properties of K-3-rh accumulated oligomers. It was noted that, a very small amount of $A \beta$ was found as precipitate during the preparation of a soluble fraction of K-3-rh pre-incubated sample, which may decrease the A $\beta$ concentration in the supernatant. To avoid the variation of $A \beta 42$ concentration and effects of precipitate $A \beta 42$, the preincubated whole samples were also included for measurement of cell death, which also showed a comparable result ( $\sim 9 \%$ cell death by A $\beta 42$ preincubated in the presence of K-3-rh for $12 \mathrm{~h}$ ) with supernatant sample (Figure $5 \mathrm{C}$ ). All of these data indicate that K-3-rh modulates the A $\beta 42$ to soluble non-toxic smaller aggregates. The results are in good accordance with our previous report that the polyphenolic flavonoids cause the accumulation of off pathway oligomers [39].

\section{K-3-rh remodels soluble toxic $A \beta$ oligomers and pre- formed fibrils to non-toxic smaller aggregates}

Our results described above suggest that K-3-rh effectively obstructs the $A \beta$ aggregation pathway and modulate to off pathway non-toxic aggregates. Next, we attempt to determine whether the flavonoid is effective for remodeling of the toxic soluble oligomers and mature fibrils. We used preformed soluble oligomers and fibrils as described in the Materials and Methods section, and characterized their aggregation and cytotoxic properties in the absence or presence of K-3-rh.

The preformed oligomers were Th- $\mathrm{T}$ negative and stable for longer than $12 \mathrm{~h}$, which converted to Th-T positive fibrillar structure when incubated for $24 \mathrm{~h}$ at $37^{\circ} \mathrm{C}$ (Figure $6 \mathrm{~A}$, gray bar and $6 \mathrm{~B}$, left and middle panel). In the presence of $40 \mu \mathrm{M} \mathrm{K}-3-\mathrm{rh}$, the oligomers were found to be Th-T negative (Figure 6A, black bar) and had mostly smaller globular structure (Figure 6B, right panel). Similarly, K-3-rh was also found to disaggregate the mature fibrils in a dose-dependent manner when coincubated with K-3-rh for $12 \mathrm{~h}$ (Figure $6 \mathrm{C}$ ). The $\mathrm{IC}_{50}$ value for the disestablishing properties of these fibrils was calculated as $>40 \mu \mathrm{M}$. The disaggregation of preformed fibrils was also investigated by employing TEM. fA $\beta 42(20 \mu \mathrm{M})$, prepared by incubation at $37^{\circ} \mathrm{C}$ for three days showed predominantly fibrils (Figure 6D, left panel). The fibrils were converted to a smaller aggregates like shape when incubated in the presence of K-3-rh for $12 \mathrm{~h}$, where dose dependent effects were also observed (Figure 6D, middle and right panels). This finding indicated that $\mathrm{K}-3$-rh disintegrates fibrils and greatly alters the fibrilar shaped to smaller aggregates. These data suggest that K-3-rh remodels the soluble oligomers and preformed fibrils to smaller aggregates. The cytotoxic properties of these converted aggregates were also measured by MTT assay. As shown in Figure 6E, higher concentrations of K-3-rh cause an effective decreased of MTT reduction, where $40 \mu \mathrm{M}$ of the compound was found to enhance cell survival by $\sim 20 \%$ against both preformed oligomers and mature fibrils. All of these data are in good agreement with the previous reports showing that polyphenolic flavonoids remodel soluble oligomers and fibrils to less-toxic smaller aggregates [50,51].

\section{Discussion}

Flavonoids have been widely reported as neuroprotective agents in several diseases including Alzheimer's and Parkinson's diseases. The cytoprotective effects of flavonoids can be revealed in three levels: antioxidation, anti-A $\beta$ aggregation, and anti-A $\beta$ induced cell death [52]. Kaempferol and its related flavonoids have been found to be effective against A $\beta$ aggregation [44], and oxidative stress [52]. Yet, the correlation of anti-amyloidogenic activity and anti-cytotoxic effect of these flavonoids remains unclear. In the current study, several flavonoids were screened for their cytoprotective effects against $A \beta 42$ peptide and the mechanisms of anti-amyloidogenic effects were explored using a polyphenolic Keamferol related flavone, K-3-rh. Most of the polyphenolic flavonoids were found to reduce the cytotoxic effects of $A \beta$ to different extents (Figure $2 \mathrm{~A}$ and $2 \mathrm{~B}$ ). Here, we focused on the properties of A 342 aggregation and its relation to cytotoxicity in the presence of K-3-rh in order to explore the mechanisms of the cytoprotective effects of the flavonoid, as well as to better understand the aggregation mechanism of the peptide.

Our findings showed that K-3-rh abrogates cytotoxic effects of $A \beta$ by hindering its on pathway self-assembly. In the presence of K-3-rh, the fibrillogenesis and structural transformation of $A \beta$ peptides were inhibited (Figure 3A-F), which leads to accumulation of several intermediate species (Figure 4A-E). The accumulated species were soluble and relatively smaller in size than toxic oligomers (Figure 5A), devoid of $\beta$-sheet fibrillar form (Figures $3 \mathrm{~F}$ and $5 \mathrm{~B}$ ) and less toxic (Figure $5 \mathrm{C}$ ), indicating that they might not be the "on pathway" aggregates. The findings are in good agreement with those of previous studies, where polyphenol (-)-epigallocatechin gallate and taiwniaflavone were found to be effective in inhibition of fibrillogenesis of $\mathrm{A} \beta$ by directly binding to the unfolded polypeptides and promoted formation of unstructured and nontoxic, off pathway, stable oligomeric structures $[39,45]$. The K-3-rh and other related flavonoids used in the current study probably redirected the $A \beta$ assembly in similar way to form non toxic off-pathway intermediated structure. The modulation of these aggregates by interaction of K-3-rh, however, might not be specific to unfolded peptides. Our results showed that $\mathrm{K}-3$-rh inhibits fibrillogenesis of $\mathrm{A} \beta 42$ peptide (Figure 3A-E), suggesting that the compound might interact with several species during aggregation. The effective inhibition of $\mathrm{A} \beta 42$ fibril extension (Figure $3 \mathrm{C}$ and 3D) demonstrates the possibility of binding of K-3-rh to the existing fibrils. The consequence of this inhibition is 


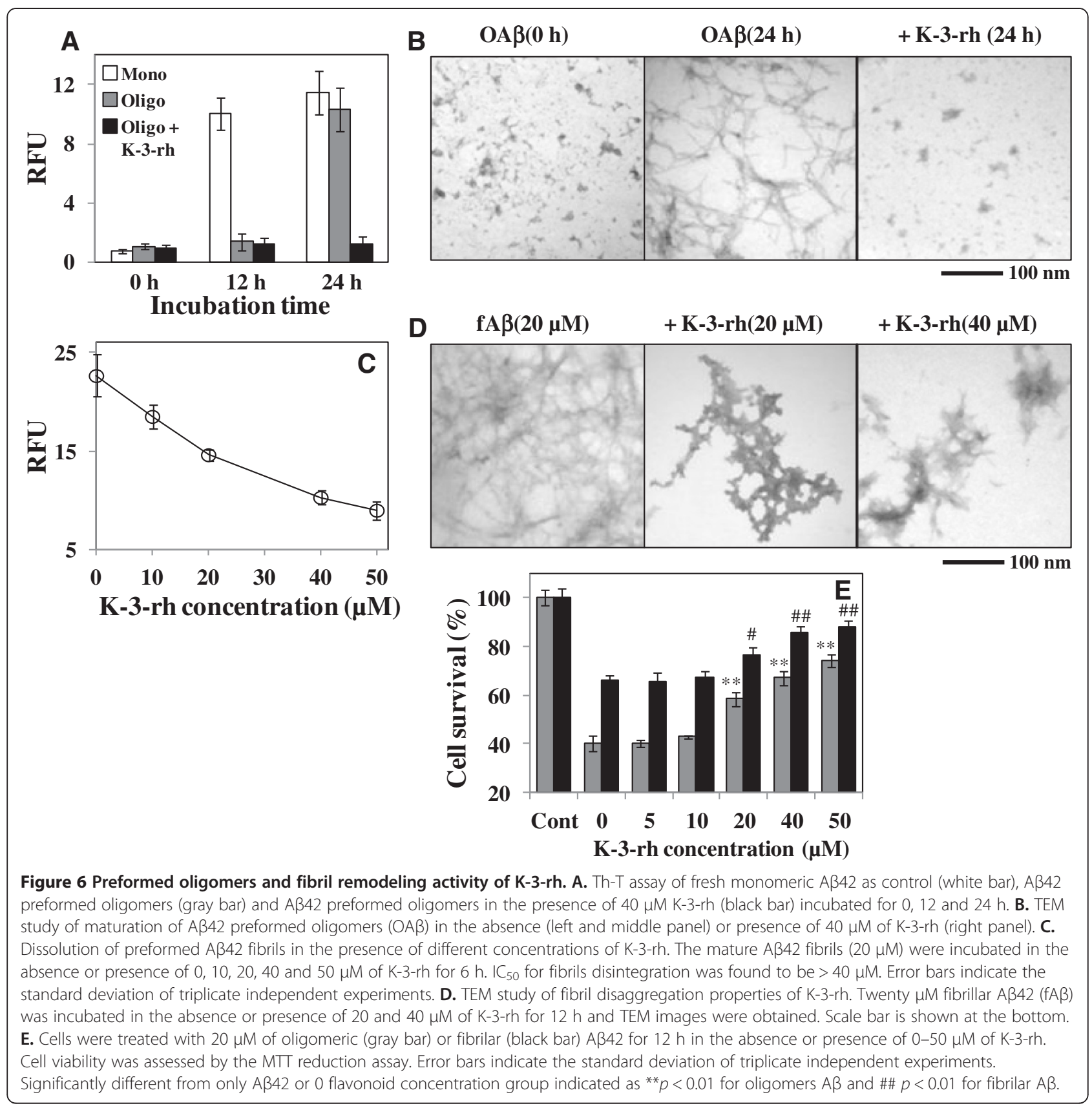

the possible alteration of the aggregation pathway of $A \beta$ by preventing it from misfolding into the $\beta$-sheet conformation (Figure 3F). Aromatic interaction between K-3-rh and aromatic residues of the $A \beta$ sequence might be a possible explanation for this inhibitory mechanism. It has been suggested that inhibitory aromatic compounds compete with polypeptide monomers for interaction with growing fibrils, and the irreversible or improved interaction by the inhibitor results in an efficient halt of the fibrillization process [53]. Only the phenolic ring by itself, however, does not efficiently inhibit amyloid formation [54] and further structural elements are necessary for the specific interaction with the amyloidogenic $\beta$-sheet conformation for creation of hydrogen bonds that enhance the stability of the inhibitor-protein complex [55]. Structural composition of K-3-rh includes three phenolic groups linked with a rhamnose moiety (Figure 1). The $\mathrm{OH}$ groups and rhamnose structure of K-3-rh probably play a supporting role for efficient interaction with $\beta$ sheet fibrils of $A \beta 42$ and hence abrogates its further assembly by forming a stable K-3-rh -A 342 complex.

The maturation of soluble oligomers is an important event in the $A \beta$ fibrillogenesis pathway. A slight change of agitation condition during $A \beta$ aggregation can result 
in development of these oligomeric forms to multiple conformers with different biochemical properties rather than following a single nucleation pathway [50]. Small molecules have also been found to convert these soluble oligomers into significantly different structural conformations [56]. Similar remodeling of soluble oligomers by $\mathrm{K}-3$-rh into a less toxic smaller $\mathrm{A} \beta 42$ conformer was also noted in the current study (Figure 6A, 6B and 6E). In addition, K-3-rh was also found to disintegrate mature fibrils (Figure $6 \mathrm{C}$ ) with an $\mathrm{IC}_{50}$ value of $40 \mu \mathrm{M}$, and to remodel them into smaller aggregates (Figure 6D) with less-toxic properties (Figure 6E). From these results, it seems clear that binding of K-3-rh is not limited to a specific $A \beta$ conformer. However, the result showing that the $\mathrm{IC}_{50}$ value of fibril disintegration was higher than that of fibril extension, suggesting the binding preference of K-3-rh to non-fibrillar A $\beta$ conformers. Because both $A \beta$ monomers and soluble oligomers possess similar secondary structure, which is different from $\beta$-sheet fibrillar structure, modulation of monomeric $A \beta$ and remodeling of toxic soluble oligomers is expected to occur in a similar manner. In the current study, both monomeric $A \beta$ (Figure 4A-E) and soluble oligomeric $A \beta$ (Figure 6B) were found to convert into smaller aggregates that were less toxic (Figures 5C and 6E). In addition, effective disaggregation properties of polyphenolic glycosidic compounds suggest that glycoside structure is an important determinant for conversion of low molecular weight aggregates from prefibrillar oligomers [51,56,57]. In the current study, the rhamnose moiety of K-3-rh structure may play a partial role in alteration of monomers to low molecular weight soluble non-toxic oligomers (Figures 4A-G and 5A) and preformed oligomers to smaller aggregates (Figure 6B), while other factors may be involved in the process. As another mechanistic approach based on structural similarities between various highly efficient polyphenol inhibitors, and relative to the well-known amyloidogenic dye Congo red, it has been suggested that common efficient polyphenol inhibitors are composed of at least two phenolic rings with two to six atom linkers, and a minimum number of three $\mathrm{OH}$ groups on the aromatic rings [55]. These structural similarities imply three-dimensional conformations that are essential for the non-covalent interaction with $\beta$-sheet structures [55]. Hence, the non-covalent interaction between $A \beta$ and K-3-rh might be a good speculation for the fibrils remodeling properties of this flavonoid.

\section{Conclusion}

Identification of small molecule inhibitors for inhibition of $\mathrm{A} \beta$ aggregation and cytotoxicity is an encouraging approach toward the therapeutic development for treatment of $\mathrm{AD}$. In the current study, we demonstrated that a mono flavonoid furnished with three $\mathrm{OH}$, three phenolic groups conjugated to a rhamnose moiety is an effective molecule for alteration of the on pathway aggregation of $A \beta$ peptide to form non-toxic off pathway conformers. The results support the model of a specific structural conformation for efficient inhibition of amyloidogenic assembly and interaction with $\beta$-sheet structure, as well as effectiveness of polyphenol glycosides in abrogation of the amyloidogenic properties of $A \beta 42$ peptide. We suggest that polyphenolic compounds with K-3-rh like structure might be good candidates for incorporation into the therapeutic strategy for treatment of $\mathrm{AD}$.

\section{Abbreviations}

$A \beta$ : Amyloid- $\beta$ peptide; AD: Alzheimer's disease; ADDLs: AB-derived diffusible ligands; APP: Amyloid precursor protein; CD: Circular dichroism spectroscopy; fAß: Fibrilar amyloid- $\beta$ peptide; GA: Gallic acid; GAME: Gallic acid methyl ester; HFIP: 1,1,1,3,3,3-hexafluoro-2-propanol; $I C_{50}$ : Concentration of the compound required to reduce the rate of polymerization, fibril extension of fresh $A \beta 42$, or destabilization of preformed $A \beta 42$ fibrils by $50 \%$; K: Keampferol; K-3-rh: Kaempferol-3-O-rhamnoside; K-3-ru: Kaempferol-3-Orutinoside; MTT: 3-(4,5-dimethylthiazol-2-yl)-2,5-diphenyltetrazolium bromide; OAß: Oligomeric amyloid- $\beta$ peptide; PA: Protocatechuic acid; PBS: Phos phate-buffered saline; PVDF: Polyvinylidene difluoride; Q: Quercitrin; Quer-dihy: Quercetin dihydrate; Quer-hy: Quercetin hydrate; SDS-PAGE: Sodium dodecyl sulfate-polyacrylamide gel electrophoresis; TEM: Transmission electron microscopy; Th-T: Thioflavin T.

\section{Competing interests}

The authors declare that they have no competing interests.

\section{Authors' contributions}

MGS performed most of the experiments, analyzed data and prepared the manuscript; AT performed some cell death assay, MS helped to purify $A \beta$, VSR performed some $A \beta$ aggregation experiments, ERW provided some phenolic compounds, SYS designed some experiments and ISP planned experiments, interpreted data and approved the version to be published. All authors read and approved the final manuscript.

\section{Acknowledgements}

This work was supported, in part, by the Research fund from Chosun University 2010. We would like to thank Mr. Soo-man Jung for TEM imaging.

\section{Author details}

${ }^{1}$ Department of Bio-materials Engineering, Chosun University, Gwanju 501-759, Republic of Korea. ${ }^{2}$ Department of Cellular and Molecular Medicine, Chosun University, Gwanju 501-759, Republic of Korea. ${ }^{3}$ College of Pharmacy, Chosun University, Gwanju 501-759, Republic of Korea. ${ }^{4}$ Department of Genetic Engineering and Biotechnology, University of Rajshahi, Rajshahi 6205, Bangladesh. ${ }^{5}$ Department of Cell Biology, University of Oklahoma Health Sciences Center, Oklahoma City, OK, USA. ${ }^{6}$ Medical School, The University of Texas Health Science Center at Houston, 6431 Fannin St, Houston, TX 77030, USA.

Received: 22 October 2012 Accepted: 20 December 2012

Published: 21 December 2012

\section{References}

1. Selkoe DJ: Alzheimer disease: mechanistic understanding predicts novel therapies. Ann Intern Med 2004, 140(8):627-638.

2. Hardy J, Selkoe DJ: The amyloid hypothesis of Alzheimer's disease: progress and problems on the road to therapeutics. Science 2002, 297(5580):353-356.

3. Haass C, Hung AY, Schlossmacher MG, Oltersdorf T, Teplow DB, Selkoe DJ: Normal cellular processing of the beta-amyloid precursor protein results in the secretion of the amyloid beta peptide and related molecules. Ann N Y Acad Sci 1993, 695:109-116. 
4. Selkoe DJ: Alzheimer's disease: genes, proteins, and therapy. Physio/ Rev 2001, 81(2):741-766.

5. Jarrett JT, Berger EP, Lansbury PT Jr: The carboxy terminus of the beta amyloid protein is critical for the seeding of amyloid formation: implications for the pathogenesis of Alzheimer's disease. Biochemistry 1993, 32(18):4693-4697.

6. Naiki H, Nakakuki K: First-order kinetic model of Alzheimer's beta-amyloid fibril extension in vitro. Lab Invest 1996, 74(2):374-383.

7. Lambert MP, Barlow AK, Chromy BA, Edwards C, Freed R, Liosatos M, Morgan TE, Rozovsky I, Trommer B, Viola KL, et al: Diffusible, nonfibrillar ligands derived from Abeta1-42 are potent central nervous system neurotoxins. Proc Natl Acad Sci U S A 1998, 95(11):6448-6453.

8. Kayed R, Head E, Thompson JL, McIntire TM, Milton SC, Cotman CW, Glabe CG: Common structure of soluble amyloid oligomers implies common mechanism of pathogenesis. Science 2003, 300(5618):486-489.

9. Nguyen HD, Hall CK: Molecular dynamics simulations of spontaneous fibril formation by random-coil peptides. Proc Natl Acad Sci U S A 2004, 101(46):16180-16185.

10. Lesne S, Koh MT, Kotilinek L, Kayed R, Glabe CG, Yang A, Gallagher M, Ashe $\mathrm{KH}$ : A specific amyloid-beta protein assembly in the brain impairs memory. Nature 2006, 440(7082):352-357.

11. Glabe CG: Conformation-dependent antibodies target diseases of protein misfolding. Trends Biochem Sci 2004, 29(10):542-547.

12. Haass C, Selkoe DJ: Soluble protein oligomers in neurodegeneration: lessons from the Alzheimer's amyloid beta-peptide. Nat Rev Mol Cell Biol 2007, 8(2):101-112

13. Frid $P$, Anisimov SV, Popovic N: Congo red and protein aggregation in neurodegenerative diseases. Brain Res Rev 2007, 53(1):135-160.

14. Begum AN, Jones MR, Lim GP, Morihara T, Kim P, Heath DD, Rock CL, Pruitt MA, Yang F, Hudspeth B, et al: Curcumin structure-function, bioavailability, and efficacy in models of neuroinflammation and Alzheimer's disease. J Pharmacol Exp Ther 2008, 326(1):196-208.

15. Solomon B: Antibody-mediated immunotherapy for Alzheimer's disease. Curr Opin Investig Drugs 2007, 8(7):519-524.

16. Soto C, Sigurdsson EM, Morelli L, Kumar RA, Castano EM, Frangione B: Betasheet breaker peptides inhibit fibrillogenesis in a rat brain model of amyloidosis: implications for Alzheimer's therapy. Nat Med 1998, 4(7):822-826.

17. Soto P, Griffin MA, Shea JE: New insights into the mechanism of Alzheimer amyloid-beta fibrillogenesis inhibition by $\mathrm{N}$-methylated peptides. Biophys J 2007, 93(9):3015-3025.

18. Yang DS, Yip CM, Huang TH, Chakrabartty A, Fraser PE: Manipulating the amyloid-beta aggregation pathway with chemical chaperones. J Biol Chem 1999, 274(46):32970-32974.

19. Necula M, Kayed R, Milton S, Glabe CG: Small molecule inhibitors of aggregation indicate that amyloid beta oligomerization and fibrillization pathways are independent and distinct. J Biol Chem 2007, 282(14):10311-10324.

20. Yang F, Lim GP, Begum AN, Ubeda OJ, Simmons MR, Ambegaokar SS, Chen PP, Kayed R, Glabe CG, Frautschy SA, et al: Curcumin inhibits formation of amyloid beta oligomers and fibrils, binds plaques, and reduces amyloid in vivo. J Biol Chem 2005, 280(7):5892-5901.

21. Pollack SJ, Sadler II, Hawtin SR, Tailor VJ, Shearman MS: Sulfonated dyes attenuate the toxic effects of beta-amyloid in a structure-specific fashion. Neurosci Lett 1995, 197(3):211-214.

22. Lee VM: Amyloid binding ligands as Alzheimer's disease therapies. Neurobiol Aging 2002, 23(6):1039-1042.

23. Spencer JP: Flavonoids: modulators of brain function? Br J Nutr 2008 99 E Suppl 1:ES60-ES77.

24. Bagchi D, Carryl OR, Tran MX, Bagchi M, Garg A, Milnes MM, Williams CB, Balmoori J, Bagchi DJ, Mitra S, et al: Acute and chronic stress-induced oxidative gastrointestinal mucosal injury in rats and protection by bismuth subsalicylate. Mol Cell Biochem 1999, 196(1-2):109-116.

25. Yamamoto Y, Gaynor RB: Therapeutic potential of inhibition of the NFkappaB pathway in the treatment of inflammation and cancer. $J$ Clin Invest 2001, 107(2):135-142.

26. Cushnie TP, Lamb AJ: Antimicrobial activity of flavonoids. Int J Antimicrob Agents 2005, 26(5):343-356

27. Commenges D, Scotet V, Renaud S, Jacqmin-Gadda H, Barberger-Gateau P, Dartigues JF: Intake of flavonoids and risk of dementia. Eur J Epidemiol 2000, 16(4):357-363.
28. Yao Z, Drieu K, Papadopoulos V: The Ginkgo biloba extract EGb 761 rescues the PC12 neuronal cells from beta-amyloid-induced cell death by inhibiting the formation of beta-amyloid-derived diffusible neurotoxic ligands. Brain Res 2001, 889(1-2):181-190.

29. Luo Y, Smith JV, Paramasivam V, Burdick A, Curry KJ, Buford JP, Khan I, Netzer WJ, Xu H, Butko P: Inhibition of amyloid-beta aggregation and caspase-3 activation by the Ginkgo biloba extract EGb761. Proc Natl Acad Sci U S A 2002, 99(19):12197-12202.

30. Ono K, Condron MM, Ho L, Wang J, Zhao W, Pasinetti GM, Teplow DB: Effects of grape seed-derived polyphenols on amyloid beta-protein selfassembly and cytotoxicity. J Biol Chem 2008, 283(47):32176-32187.

31. Rigacci S, Guidotti V, Bucciantini M, Nichino D, Relini A, Berti A, Stefani M: Abeta(1-42) aggregates into non-toxic amyloid assemblies in the presence of the natural polyphenol oleuropein aglycon. Curr Alzheimer Res 2011, 8(8):841-852

32. Qin XY, Cheng Y, Yu LC: Potential protection of green tea polyphenols against intracellular amyloid beta-induced toxicity on primary cultured prefrontal cortical neurons of rats. Neurosci Lett 2012, 513(2):170-173.

33. Kim JK, Choi SJ, Cho HY, Hwang HJ, Kim YJ, Lim ST, Kim CJ, Kim HK Peterson S, Shin DH: Protective effects of kaempferol $\left(3,4^{\prime}, 5,7-\right.$ tetrahydroxyflavone) against amyloid beta peptide (Abeta)-induced neurotoxicity in ICR mice. Biosci Biotechnol Biochem 2010, 74(2):397-401.

34. Lu JH, Ardah MT, Durairajan SS, Liu LF, Xie LX, Fong WF, Hasan MY, Huang JD, El-Agnaf OM, Li M: Baicalein Inhibits Formation of alpha-Synuclein Oligomers within Living Cells and Prevents Abeta Peptide Fibrillation and Oligomerisation. Chembiochem 2011, 12(4):615-624.

35. Feng $Y$, Wang XP, Yang SG, Wang YJ, Zhang X, Du XT, Sun XX, Zhao M, Huang L, Liu RT: Resveratrol inhibits beta-amyloid oligomeric cytotoxicity but does not prevent oligomer formation. Neurotoxicology 2009, 30(6):986-995.

36. Ramassamy C: Emerging role of polyphenolic compounds in the treatment of neurodegenerative diseases: a review of their intracellular targets. Eur J Pharmacol 2006, 545(1):51-64.

37. Lee CW, Choi HJ, Kim HS, Kim DH, Chang IS, Moon HT, Lee SY, Oh WK, Woo ER: Biflavonoids isolated from Selaginella tamariscina regulate the expression of matrix metalloproteinase in human skin fibroblasts. Bioorg Med Chem 2008, 16(2):732-738.

38. Shahnawaz M, Thapa A, Park IS: Stable activity of a deubiquitylating enzyme (Usp2-cc) in the presence of high concentrations of urea and its application to purify aggregation-prone peptides. Biochem Biophys Res Commun 2007, 359(3):801-805.

39. Thapa A, Woo ER, Chi EY, Sharoar MG, Jin HG, Shin SY, Park IS: Biflavonoids Are Superior to Monoflavonoids in Inhibiting Amyloid-beta Toxicity and Fibrillogenesis via Accumulation of Nontoxic Oligomer-like Structures. Biochemistry 2011, 50(13):2445-2455.

40. Naiki H, Hasegawa K, Yamaguchi I, Nakamura H, Gejyo F, Nakakuki K: Apolipoprotein $E$ and antioxidants have different mechanisms of inhibiting Alzheimer's beta-amyloid fibril formation in vitro. Biochemistry 1998, 37(51):17882-17889.

41. Kirkitadze MD, Condron MM, Teplow DB: Identification and characterization of key kinetic intermediates in amyloid beta-protein fibrillogenesis. J Mol Biol 2001, 312(5):1103-1119.

42. Moss MA, Varvel NH, Nichols MR, Reed DK, Rosenberry TL: Nordihydroguaiaretic acid does not disaggregate beta-amyloid(1-40) protofibrils but does inhibit growth arising from direct protofibril association. Mol Pharmacol 2004, 66(3):592-600

43. Zou K, Gong JS, Yanagisawa K, Michikawa M: A novel function of monomeric amyloid beta-protein serving as an antioxidant molecule against metal-induced oxidative damage. J Neurosci 2002, 22(12):4833-4841.

44. Ono K, Yoshiike Y, Takashima A, Hasegawa K, Naiki H, Yamada M: Potent anti-amyloidogenic and fibril-destabilizing effects of polyphenols in vitro: implications for the prevention and therapeutics of Alzheimer's disease. J Neurochem 2003, 87(1):172-181.

45. Masuda M, Suzuki N, Taniguchi S, Oikawa T, Nonaka T, Iwatsubo T, Hisanaga S, Goedert M, Hasegawa M: Small molecule inhibitors of alpha-synuclein filament assembly. Biochemistry 2006, 45(19):6085-6094.

46. Chromy BA, Nowak RJ, Lambert MP, Viola KL, Chang L, Velasco PT, Jones BW, Fernandez SJ, Lacor PN, Horowitz P, et al: Self-assembly of Abeta(142) into globular neurotoxins. Biochemistry 2003, 42(44):12749-12760.

47. Walsh DM, Hartley DM, Kusumoto Y, Fezoui Y, Condron MM, Lomakin A, Benedek GB, Selkoe DJ, Teplow DB: Amyloid beta-protein fibrillogenesis. 
Structure and biological activity of protofibrillar intermediates. J Biol Chem 1999, 274(36):25945-25952.

48. McLean CA, Cherny RA, Fraser FW, Fuller SJ, Smith MJ, Beyreuther K, Bush Al, Masters CL: Soluble pool of Abeta amyloid as a determinant of severity of neurodegeneration in Alzheimer's disease. Ann Neurol 1999, 46(6):860-866.

49. Tomic JL, Pensalfini A, Head E, Glabe CG: Soluble fibrillar oligomer levels are elevated in Alzheimer's disease brain and correlate with cognitive dysfunction. Neurobiol Dis 2009, 35(3):352-358.

50. Ladiwala AR, Lin JC, Bale SS, Marcelino-Cruz AM, Bhattacharya M, Dordick JS, Tessier PM: Resveratrol selectively remodels soluble oligomers and fibrils of amyloid Abeta into off-pathway conformers. J Biol Chem 2010, 285(31):24228-24237.

51. Ladiwala AR, Mora-Pale M, Lin JC, Bale SS, Fishman ZS, Dordick JS, Tessier PM: Polyphenolic glycosides and aglycones utilize opposing pathways to selectively remodel and inactivate toxic oligomers of amyloid beta. Chembiochem 2011, 12(11):1749-1758

52. Zhu JT, Choi RC, Chu GK, Cheung AW, Gao QT, Li J, Jiang ZY, Dong TT, Tsim KW: Flavonoids possess neuroprotective effects on cultured pheochromocytoma PC12 cells: a comparison of different flavonoids in activating estrogenic effect and in preventing beta-amyloid-induced cell death. J Agric Food Chem 2007, 55(6):2438-2445.

53. Porat Y, Mazor Y, Efrat S, Gazit E: Inhibition of islet amyloid polypeptide fibril formation: a potential role for heteroaromatic interactions. Biochemistry 2004, 43(45):14454-14462.

54. Nakagami Y, Nishimura S, Murasugi T, Kaneko I, Meguro M, Marumoto S, Kogen H, Koyama K, Oda T: A novel beta-sheet breaker, RS-0406, reverses amyloid beta-induced cytotoxicity and impairment of long-term potentiation in vitro. Br J Pharmacol 2002, 137(5):676-682.

55. Porat Y, Abramowitz A, Gazit E: Inhibition of amyloid fibril formation by polyphenols: structural similarity and aromatic interactions as a common inhibition mechanism. Chem Biol Drug Des 2006, 67(1):27-37.

56. Ladiwala AR, Dordick JS, Tessier PM: Aromatic small molecules remodel toxic soluble oligomers of amyloid beta through three independent pathways. J Biol Chem 2011, 286(5):3209-3218.

57. Ladiwala AR, Perchiacca JM, Fishman ZS, Bhattacharya M, Hickey AM, Domigan BG, Dordick JS, Tessier PM: Polyphenolic disaccharides endow proteins with unusual resistance to aggregation. Biotechnol Bioeng 2012, 109(7):1869-1874.

doi:10.1186/1423-0127-19-104

Cite this article as: Sharoar et al.: Keampferol-3-O-rhamnoside abrogates amyloid beta toxicity by modulating monomers and remodeling oligomers and fibrils to non-toxic aggregates. Journal of Biomedical Science 2012 19:104.

\section{Submit your next manuscript to BioMed Central and take full advantage of:}

- Convenient online submission

- Thorough peer review

- No space constraints or color figure charges

- Immediate publication on acceptance

- Inclusion in PubMed, CAS, Scopus and Google Scholar

- Research which is freely available for redistribution 